\title{
PINTEREST SEBAGAI MEDIA REFERENSI VISUAL PADA MATAKULIAH PERANCANGAN ARSITEKTUR
}

\author{
Muhammad Heru Arie Edytia ${ }^{1}$, Zulhadi Sahputra ${ }^{2}$ \\ ${ }^{1}$ Program Studi Arsitektur, Jurusan Arsitektur dan Perencanaan, Fakultas Teknik, Universitas Syiah \\ Kuala, email: muhammad.heru@unsyiah.ac.id \\ ${ }^{2}$ Program Studi Arsitektur, Jurusan Arsitektur dan Perencanaan, Fakultas Teknik, Universitas Syiah \\ Kuala, email: zulhadi.sahputra@unsyiah.ac.id
}

\begin{abstract}
ABSTRAK
Pembelajaran Jarak Jauh (PJJ) harus diberlakukan pada matakuliah Perancangan Arsitektur di Program Studi Arsitektur Universitas Syiah Kuala yang berbasis studio sejak Maret 2020 sebagai akibat dari tindakan pemutusan rantai penyebaran COVID-19 di lingkungan kampus. Pengajar atau dosen arsitektur terpaksa mentransformasi metode pembelajaran dari tatap muka secara intensif yang biasa dilakukan di studio menjadi PJJ melalui metode dalam jaringan (daring). Begitu halnya peserta didik, mahasiswa arsitektur yang menjalani proses pembelajaran arsitektural secara daring harus siap memanfaatkan berbagai media pembelajaran. Salah satu media referensi visual yang populer digunakan adalah Pinterest. Meskipun Pinterest telah banyak dan populer digunakan sebelum PJJ diberlakukan, media yang diluncurkan pada Maret 2010 ini mampu menjadi media rujukan visual utama bagi dosen dan mahasiswa arsitektur layaknya fasilitator atau dosen pembimbing. Oleh karena itu, tulisan ini bertujuan untuk merefleksikan penggunaan Pinterest sebagai media referensi visual bagi dosen dan mahasiswa pada matakuliah Perancangan Arsitektur (PA) dan pengembangannya selama proses pembelajaran jarak jauh (PJJ). Refleksi ini dimulai dari deskripsi fitur-fitur dan kaitannya dengan proses desain pada matakuliah PA. Refleksi ditutup dengan menjabarkan kemungkinan pengembangan pemanfaatan Pinterest sebagai proses pembelajaran arsitektur. Pada akhirnya Pinterest dapat menjadi media alternatif yang membantu proses desain pada matakuliah PA.
\end{abstract}

Kata kunci: media, perancangan arsitektur, pinterest, refleksi

Info Artikel:

Dikirim: 23 Maret 2021; Revisi: 25 Maret 2021; Diterima: 31 Maret 2021; Diterbitkan: 31 Maret 2021

(C2021 The Author(s). Published by Arsitekno, Architecture Program, Universitas Malikussaleh, Aceh, Indonesia under the Creative Commons Attribution 4.0 International License (https://creativecommons.org/licenses/by/4.0/).

\section{PENDAHULUAN}

Sejak Maret 2020, pembelajaran tatap muka yang biasa dilakukan di lingkungan perguruan tinggi dilakukan secara dalam jaringan (daring). Proses peralihan ini dimaksudkan untuk memutuskan rantai penyebaran COVID-19 yang telah memakan korban di Indonesia sejak Februari 2020. Penyebaran virus yang menyebar melalui droplet ini dengan mudah ditularkan melalui hubungan interaksi tatap muka langsung yang biasa dilakukan pada proses pembelajaran di kelas. Peralihan yang cukup mendadak ini menjadi tantangan tersendiri bagi dosen sebagai pendidik dan mahasiswa sebagai peserta didik. Sebagai dosen, tantangan-tantangan yang dihadapi mulai dari eksplorasi penggunaan media pembelajaran daring, adaptasi materi pembelajaran hingga adaptasi proses penilaian dari tatap muka di kelas menjadi pembelajaran jarak jauh (PJJ). Tantangan ini diperparah dengan kehidupan domestik yang harus berubah dan bergabung dengan aktifitas bekerja [1] karena setiap individu harus menghindari kerumunan dan bekerja dari rumah. Faktor terakhir juga menjadi tantangan bagi mahasiswa yaitu melakukan kegiatan perkuliahan dan tugas pada kondisi domestik yang berubah di waktu yang bersamaan.

Tantangan ini tentunya dialami oleh dosen dan mahasiswa arsitektur pada proses pembelajaran terutama matakuliah berbasis studio. Matakuliah berbasis studio sudah sejak lama diketahui harus dilakukan melalui proses panjang, tatap muka, diskusi grup dan pembimbingan 
yang intensif antara dosen dan mahasiswa [2]. Namun, kegiatan-kegiatan ini wajib bertransformasi menjadi PJJ. Jika pada saat tatap muka, proses tutorial, workshop, bimbingan, hingga evaluasi dapat dilakukan dengan mudah dan terstruktur, berbeda halnya ketika coretan sebagai salah satu proses umpan balik harus dilakukan melalui daring. Dengan kata lain, tidak sepenuhnya substansi umpan balik dari fasilitator atau dosen mampu tersampaikan dengan baik kepada mahasiswa. Meskipun demikian, dosen matakuliah Perancangan Arsitektur (PA) harus memberikan umpan balik yang efektif. Umpan balik yang efektif secara berkala selain menghindari terjadinya plagiarisme dan sebagai apresiasi juga memastikan terciptanya interaksi untuk meningkatkan kompetensi [3] [4].

Salah satu penyesuaian yang dilakukan pada proses PJJ berbasis studio ini adalah bereksplorasi menggunakan media atau platform baru. Penyesuaian ini tidak hanya pada penggunaan platform tetapi juga penyesuaian substansi materi studio yang harus beradaptasi [3]. Pengadaptasian materi studio dari luar jaringan (luring) menjadi daring sudah pasti menghasilkan proses yang berbeda karena tidak sepenuhnya materi saat luring harus disampaikan dan diselesaikan. Pada akhirnya, ketuntasan capaian pembelajaran harus diraih dengan berbagai penyesuaian metode pengajaran.

Berbagai platform dapat digunakan untuk mengadaptasi proses pembelajaran di studio baik secara sinkron maupun asinkron. Proses pembelajaran berbasis studio ini meliputi pengarahan (briefing), pemberian materi ajar (tutorial), lokakarya (workshop), pembimbingan (mentoring), evaluasi (review), pengumpulan tugas (submission), dan pameran (exhibition). Pada tulisan ini, platform yang akan dibahas adalah Pinterest sebagai media referensi visual yang membantu proses pemberian materi ajar oleh dosen dan lokakarya oleh mahasiswa. Meskipun penggunaan platform ini bukan tergolong baru, penggunaan website dan aplikasi mobile tersebut meningkat seiring dengan proses PJJ dilakukan. Kedua pihak, mahasiswa dan dosen, merujuk pada Pinterest sebagai sumber referensi visual salah satunya untuk preseden proyek matakuliah PA. Hal yang menjadi menarik adalah mahasiswa menjadikan referensi visual yang diperoleh dari Pinterest sebagai sumber utama tanpa narasi [5] dan penelaahan lebih lanjut.

Berdasarkan hasil penjabaran latar belakang di atas, tulisan ini bertujuan untuk merefleksikan penggunaan Pinterest sebagai media dan alat yang digunakan pada proses desain pada matakuliah PA selama PJJ. Refleksi ini juga berusaha menjabarkan kemungkinan pengembangan dan pemanfaatan Pinterest untuk mendukung pembelajaran matakuliah PA berbasis studio secara daring.

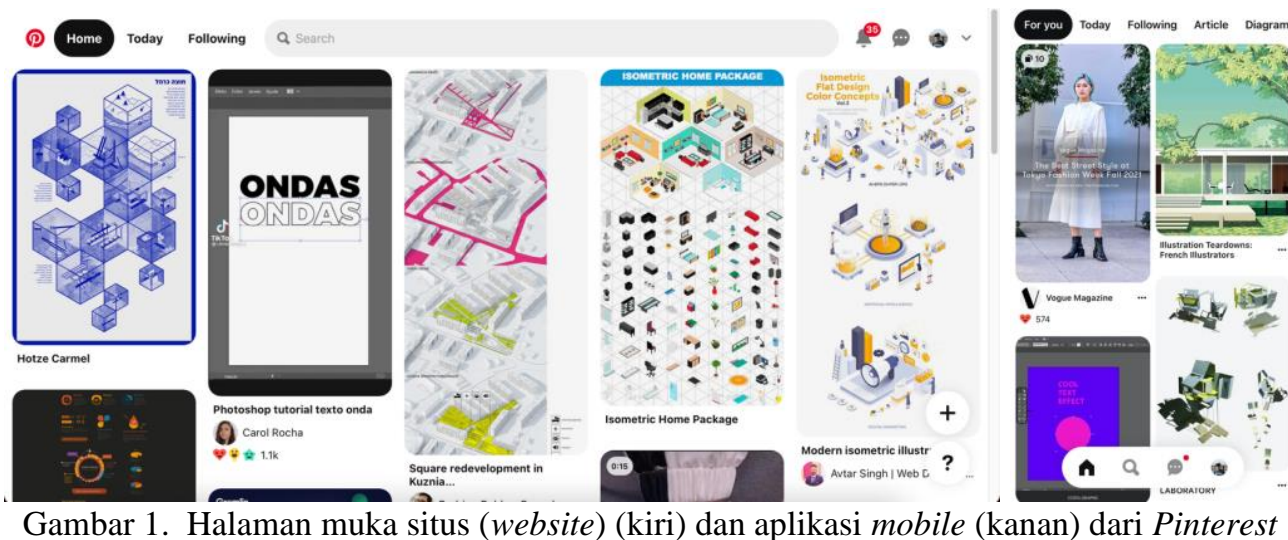

\section{METODE}

Tulisan ini sebagai refleksi penggunaan media atau platform Pinterest bagi dosen dan mahasiswa pada matakuliah PA. Refleksi ini didahului dengan definisi dan penggunaan media Pinterest. Penulis memberikan contoh bagaimana mahasiswa arsitektur di Program Studi Arsitektur Universitas Syiah Kuala memanfaatkan penggunaan platform dengan metode pin ini sebagai alat dan media untuk membantu proses desain. Tulisan ini diakhiri dengan pengembangan media yang dapat dilakukan sebagai media atau platform PJJ. 


\section{HASIL DAN PEMBAHASAN}

\section{Pinterest sebagai 'Fasilitator' dan 'Pembimbing'}

Pencarian topik-topik yang diinginkan dengan mudah lalu mengelompokkannya sesuai tema menjadi salah satu fitur terbaik Pinterest sehingga digunakan dosen dan mahasiswa arsitektur. Pencarian yang dilakukan melalui Pinterest lebih akurat dibandingkan mesin pencari daring lainnya. Disisi lain, fitur ini dimanfaatkan mahasiswa secara praktis dan menjadikannya referensi tanpa memperhatikan hak cipta dan proses desain di balik preseden [5].

Layaknya fasilitator dan dosen pembimbing yang mampu memberi informasi dan arahan pada proses desain, fitur-fitur Pinterest juga mampu memberikan informasi yang lebih luas kepada mahasiswa peserta matakuliah PA. Informasi-informasi ini berupa referensi visual untuk keperluan proses studio seperti preseden. Fitur layaknya media sumber informasi ini memberikan dampak negatif sekaligus positif kepada mahasiswa.

Dwiagmi [5] mengungkapkan bahwa Pinterest mengaburkan kearifan lokal dengan cara menyajikan informasi referensi-referensi yang cenderung kontemporer. Sementara itu, penulis melihat ini adalah keunggulan fitur Pinterest. Pinterest tidak membatasi pencarian sehingga mahasiswa lebih tertarik pada referensi desain kontemporer melainkan kata kunci (keyword) yang dimasukkan dan ketersediaan referensi pada papan (board). Hal yang dapat dilakukan adalah menambahkan referensi visual preseden lokal pada board. Selanjutnya, penulis setuju dengan Dwiagmi [5] bahwa mahasiswa dengan mudah menjadikan referensi visual yang diperoleh pada laman Pinterest tanpa menelusuri sumber spesifik. Keadaan ini berakibat pada menurunnya kemampuan analisis mahasiswa untuk melihat proses desain di balik preseden tersebut.

Sebuah penelitian yang dilakukan pada tahun 2006 oleh Clarke, Flaherty dan Yankey di dalam Hansen dkk [6] menyatakan bahwa 40\% mahasiswa adalah orang yang belajar dari visual. Oleh karena itu, pembuatan papan (board) yang berisi contoh-contoh gambar bisa menjadi pilihan bagi dosen pembimbing untuk memberikan informasi yang baik dibandingkan mahasiswa mencari sumber tanpa narasi.

\section{Pinterest sebagai Pinboard}

Sebelum proses pembelajaran studio dilakukan secara jarak jauh, mahasiswa peserta matakuliah PA diwajibkan untuk melakukan penempelan (pin up) materi presentasi dan perkembangan (progress) desain pada papan presentasi atau dinding secara tradisional. Pada tahap ini, dosen pembimbing atau fasilitator akan memberikan umpan balik (feedback) pada setiap tempelan materi tersebut. Untuk proyek studio yang mengharuskan dikerjakan berkelompok, tempelan ini berfungsi sebagai media kolaborasi yang menyajikan data, hasil analisis hingga hasil sintesis. Lebih lanjut, tempelan-tempelan ini juga berisi referensi-referensi yang akan digunakan pada proses desain tersebut.

Sebagai tambahan, proses tempelan ini tidak hanya bermanfaat bagi individu mahasiswa atau kelompok kolaborasi, tetapi bagi mahasiswa peserta matakuliah PA dari kelompok yang berbeda. Tempelan ini menjadi referensi bagi peserta atau kelompok lain. Pada akhirnya, terjadi interaksi antar mahasiswa yang akan menambah wawasan pada proses desain.

Mirip dengan metode tempelan yang dijelaskan di atas, Pinterest, media yang berbasis pin (pin) dan papan (board) ini telah banyak digunakan sebagai media untuk mencari referensi visual, merencanakan dan mengaturnya di dalam papan-papan topik tertentu sejak tahun 2010 [6]. Setiap mahasiswa dapat berkolaborasi mengumpulkan, mengunggah, dan mengelompokkan hasil temuan di media daring dan atau hasil analisis dan sintesis melalui Pinterest.

Jika proses menempel dilakukan secara individu, mahasiswa hanya tinggal mengundang atau mengirimkan link kepada dosen pembimbing melalui email. Kolaborasi antar mahasiswa dilakukan dengan mengirimkan lebih banyak peserta dalam satu papan (board). Tetapi tidak menutup kemungkinan, hasil pin satu kelompok dapat dilihat bagi mahasiswa lain dan dikomentari secara sinkron dan asinkron pada kolom komentar. Keadaan ini tetap menjamin interaksi antar mahasiswa dan dosen pembimbing dapat terjadi meskipun tidak seaktif ketika dilakukan secara langsung di studio. 


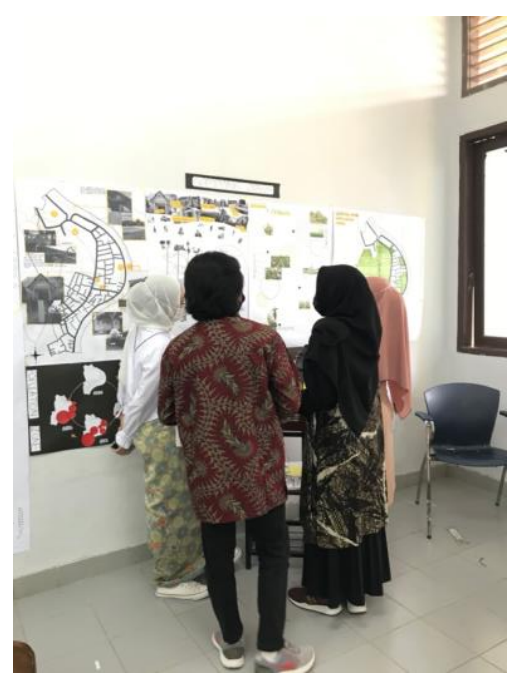

Gambar 2. Proses kolaborasi melalui pin up pada matakuliah PA III semester genap 2020/2021 di Program Studi Arsitektur Universitas Syiah Kuala.

Kelebihan proses pin pada Pinterest juga memberi kemudahan bagi fasilitator atau dosen pembimbing untuk menelusuri (tracing) sumber referensi visual yang telah dilakukan mahasiswa. Fasilitator dengan cepat memberikan umpan balik jika referensi tidak menjelaskan dan memberikan informasi yang berguna.

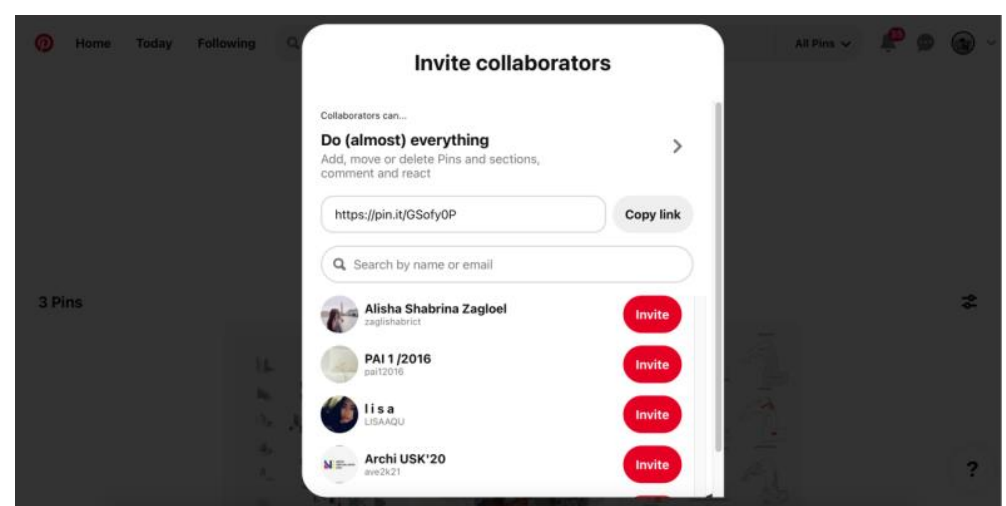

Gambar 3. Proses mengirimkan undangan kolaborasi pada Pinterest.

\section{Pengembangan Media Pinterest}

Bagian sebelumnya telah menjelaskan refleksi penggunaan Pinterest pada matakuliah PA melalui tahap memberikan materi (tutorial) dan lokakarya (workshop). Pertanyaan selanjutnya adalah apakah Pinterest dapat dikembangkan dan dimanfaatkan pada tahap lainnya untuk mendukung proses pembelajaran jarak jauh?

Pengembangan yang telah dilakukan oleh mahasiswa Program Studi Arsitektur Universitas Syiah Kuala adalah tahap memamerkan hasil karya akhir dari proyek. Mahasiswa peserta matakuliah Perancangan Dasar semester ganjil 2020/2021 membuat halaman di Pinterest untuk memamerkan karya tugas mingguan hingga tugas akhir. Mahasiswa tersebut mengelompokkan karya-karya sesuai dengan proyek yang dilakukan setiap minggu. Berbeda halnya dengan mahasiswa peserta matakuliah PA II semester ganjil 2020/2021. Mahasiswa peserta PA II tidak mengelompokkan hasil karya berdasarkan progress mingguan dan hanya mengunggah portfolio maket akhir.

Pemanfaatan platform Pinterest untuk tahap pameran akhir dilakukan sebagai alternatif selain Instagram. Fitur pencarian Pinterest yang lebih akurat membuat eksistensi karya mahasiswa sebagai salah satu tujuan diadakan pameran lebih baik dibandingkan platform Instagram. Namun, fitur unduh pada Pinterest dapat memberikan kesempatan kepada pihak lain untuk melakukan plagiasi jika portfolio tidak diberi markah (watermark). Oleh karena itu, setiap portfolio yang diunggah ke Pinterest sebaiknya diberi markah. 


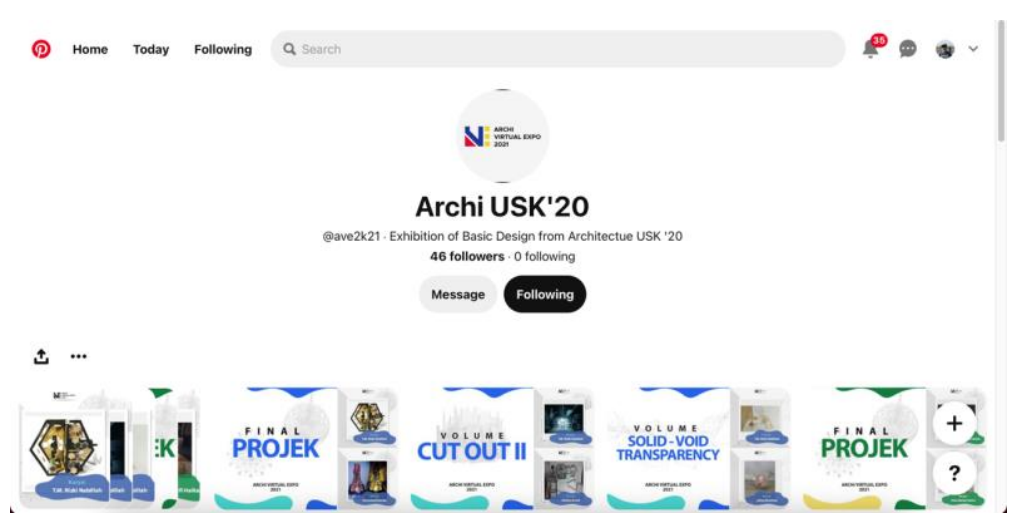

Gambar 4. Halaman muka pameran akhir matakuliah Perancangan Dasar semester ganjil 2020/2021 pada Prodi Arsitektur Universitas Syiah Kuala

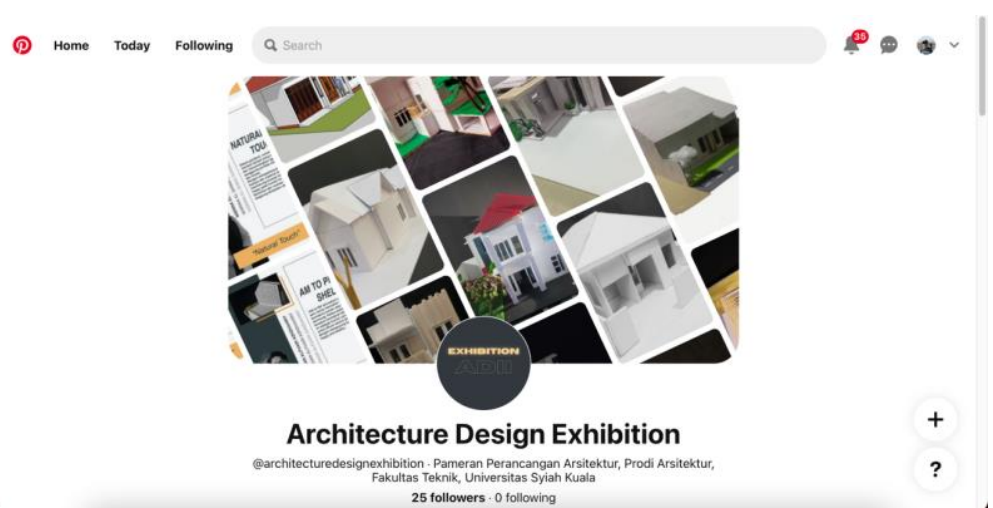

Gambar 5. Halaman muka pameran akhir matakuliah PA II semester ganjil 2020/2021 pada Prodi Arsitektur Universitas Syiah Kuala

Pembuatan papan-papan visual baru pada Pinterest dapat membuat tren berpotensial dan menyebarkan wawasan yang baru dan berbeda melalui teknologi komunikasi yang dimediasi oleh komputer (computer-mediated communication) [7].

\section{KESIMPULAN DAN SARAN}

Secara umum, proses desain yang dilakukan pada matakuliah PA berbasis studio adalah pengarahan awal (briefing), pemberian materi (tutorial), lokakarya (workshop), bimbingan (mentoring), evaluasi (review), pengumpulan (submission), dan pameran (exhibition). Berdasarkan hasil pembahasan, minimal tiga dari tujuh proses desain tersebut dapat dilakukan melalui media atau platform Pinterest. Tiga proses desain ini membantu dosen dan mahasiswa arsitektur pada proses pembelajaran yang mulai dilakukan secara jarak jauh sebagai akibat dari pandemi COVID-19 yaitu pemberian materi (tutorial), lokakarya (workshop), dan pameran (exhibition).

Pada proses pemberian materi, Pinterest mampu menyajikan dengan cepat dan akurat sumber referensi visual bagi dosen. Sumber referensi ini juga dimanfaatkan oleh mahasiswa pada proses lokakarya (workshop). Terakhir, dengan memanfaatkan Pinterest sebagai papan pameran, mahasiswa berkolaborasi membuat portfolio hasil karya (exhibition). Fitur-fitur ini membuat Pinterest menjadi pilihan platform yang dapat dimanfaatkan dan dikembangkan sebagai bagian dari proses pembelajaran jarak jauh berbasis studio.

\section{DAFTAR PUSTAKA}

[1] A. Karimah and K. Paramita, "Investigating the Domestic Layers Adaptation During Pandemic", Interiority, vol. 3, no. 2, pp. 185-200, 2020.

[2] L. Ahmad, M. Sosa, and K. Musfy, "Interior Design Teaching Methodology During the Global COVID-19 Pandemic," Interiority, vol. 3, no. 2, pp. 163-184, 2020. 
[3] P. Atmodiwirjo and Y. Yatmo, Transformasi Pendidikan Arsitektur: Sebuah Catatan Pembelajaran Jarak Jauh. Depok: Departemen Arsitektur Universitas Indonesia, 2020.

[4] R. Conaway, S. Easton and W. Schmidt, "Strategies for Enhancing Student Interaction and Immediacy in Online Courses", Business Communication Quarterly, vol. 68, no. 1, pp. 23-35, 2005.

[5] J. Dwiagmi and G. Purwoko, in ENVISI 2020, 2020, pp. 168-174.

[6] K. Hansen, G. Nowlan and C. Winter, "Pinterest as a Tool: Applications in Academic Libraries and Higher Education", Partnership: The Canadian Journal of Library and Information Practice and Research, vol. 7, no. 2, 2012.

[7] I. Mull and S. Lee, "PIN" pointing the motivational dimensions behind Pinterest", Computers in Human Behavior, vol. 33, pp. 192-200, 2014. 